\title{
BURUNG STRATA BAWAH (UNDESTORY) DI HUTAN PEGUNUNGAN TAMAN NASIONAL KERINCI SEBLAT (TNKS) KERINCI JAMBI
}

\author{
Liza Meini Fitri, Heru Handika, Inda Dwi Solina \\ Museum Zoology Universitas Andalas \\ Jl. Taratak Paneh Korong Gadang, Kuranji, Padang, \\ Email : sii_pidhi@yahoo.com
}

\begin{abstract}
Birds are one of the biological wealth owned by Indonesia. The structure of the lower strata of bird communities in tropical areas represent a very good system to see the difference in sensitivity between species for habitat variation in different scales. This study was conducted in January 2013 using the method of net Mist (mist nets) in the Kerinci National Park (TNKS). Birds that are found as many as 21 species to 83 people only order passerines with six families. The diversity of birds affected by many factors diantarannya abundance of epiphytes, an abundance of fruits, the openness of the forest floor and tree species composition. Generally mountainous forest area will have a relatively high number of species ang.
\end{abstract}

Key word: Undestory, Birds, TNKS

\section{PENDAHULUAN}

Indonesia menduduki peringkat keempat Negara-negara yang kaya akan jenis burung dan menduduki peringkat pertama di dunia berdasarkan jumlah jenis endemik (Sujatnika et.al, 1995) Saat ini 1598 spesies burung dari 9000 spesies burung di dunia terdapat di Indonesia. Dari jumlah tersebut $372(23,28 \%)$ spesies diantaranya endemik, 149 (9,32\%) spesies burung migran dan sangat disayangkan sekali di Indonesia tercatat 118 (7,38\%) spesies burung dikategorikan sebagai spesies yang terancam punah (Sukmantoro et.al 2007).

Burung memiliki nilai ekonomi, estetika dan budaya yang tinggi. Burung merupakan indikator terbaik untuk mengetahui kondisi keanekaragaman hayati karena kelompok satwa ini memiliki sifat-sifat yang mendukung yaitu, (1) Hidup pada semua jenis habitat di seluruh dunia; (2) Peka terhadap perubahan lingkungan; (3) taksonomi burung relatif lebih berkembang; (4) informasi mengenai penyebaran berdasarkan geografi setiap spesies burung di dunia telah diketahui dan terdokumentasi dengan baik (Sujatnika et.al, 1995). Dengan demikian keberadaan jenis burung dapat menjadi dasar untuk membuat keputusan mengenai rencana strategi konservasi yang lebih luas baik terhadap jenis burung itu sendiri ataupun habitatnya (Bibby et.al, 2000).

Burung strata bawah didefinisikan sebagai spesies yang menggunakan daerah understory (sampai ketinggian 3 meter dari permukaan tanah) untuk daerah mencari makan dan bersarang. Struktur komunitas burung strata bawah di daerah tropis mewakili system yang sangat baik untuk melihat perbedaan sensitifitas antar spesies terhadap variasi habitat dalam skala yang berbeda (Willson and Comet, 1996). Pengkatogorian ini bisa dilakukan dengan cara mencari informasi pustaka atau pengamatan langsung di lapangan. Dalam penelitian ini, burung strata bawah didefinisikan seagai burung yang tertangkap dalam jarring kabut yang dipasanng pada ketinggian 20 sampai 30 $\mathrm{cm}$ dari permukaan tanah (Novarino, et al, 2008)

Keanekaragaman jenis burung dipengaruhi oleh keanekaragaman tipe habitat. Struktur vegetasi dan ketersediaan pakan pada habitat merupakan faktor utama yang mempengaruhi keanekaragaman jenis di suatu 
habitat, sehingga habitat dengan variasi vegetasi lebih beragam akan memiliki keanekaragaman jenis burung yang lebih tinggi dibandingkan dengan habitat yang memiliki sedikit jenis vegetasi. Berdasarkan pemikiran tersebut, maka pelitian ini dilakukan dengan tujuan untuk tujuan mengetahui jenis burung strata bawah (understory) di kawasan hutan pegunungan Taman Nasional Kerinci Seblat.

\section{METODE PENELITIAN}

Penelitian ini dilaksanakan mulai bulan Januari 2013 di kawasan pegunungan Taman Nasional Kerinci Seblat pengambilan data dilakukan di Gunung Kerinci diketinggian 1909 mdpl dan Gunung Tujuh di ketinggian 1600 mdpl sebagai perwakilan kawasan pegunungan di TNKS.

Tabel 1. Jenis Burung di Taman Nasional Kerinci Seblat Kerinci

\begin{tabular}{|c|c|c|c|c|}
\hline Ordo & Famili & Spesies & Nama Indonesia & Nama Inggris \\
\hline \multirow[t]{21}{*}{ Passeriformes } & Turdidae & Myiophoneus glaucinus & $\begin{array}{l}\text { Ciungbatu kecil- } \\
\text { sunda }\end{array}$ & $\begin{array}{l}\text { sunda whistling } \\
\text { thursh }\end{array}$ \\
\hline & Turdidae & Myopinius melanorus & $\begin{array}{l}\text { Ciungbatu } \\
\text { sumatera }\end{array}$ & shiny whistling \\
\hline & Turdidae & Zoothera siberica & Anis siberica & siberian thrush \\
\hline & Turdidae & Bryciopteryx leucophrys & Cingcoang coklat & lesser shortwing \\
\hline & Timaliidae & Stachyris nigriceps & $\begin{array}{l}\text { Tepus kepala } \\
\text { hitam }\end{array}$ & $\begin{array}{l}\text { Grey-throated } \\
\text { babbler }\end{array}$ \\
\hline & Timaliidae & Stachyris cresaea & Tepus emas & golden babbler \\
\hline & Timaliidae & Phoepyga pucilla & Berencet kerdil & pygmy wren-babbler \\
\hline & Timaliidae & Naphotera rufipectus & $\begin{array}{l}\text { Berencet dada } \\
\text { karat }\end{array}$ & $\begin{array}{l}\text { rusty-breasted wren } \\
\text { babbler }\end{array}$ \\
\hline & Timaliidae & Rimator malacoptilus & $\begin{array}{l}\text { Berencet } \\
\text { sumatera }\end{array}$ & $\begin{array}{l}\text { long-billed wren- } \\
\text { babbler }\end{array}$ \\
\hline & Timaliidae & Stachyris striolata & Tepus lurik & spot-necked babbler \\
\hline & Muscicapidae & Niltava grandis & $\begin{array}{l}\text { Niltava } \\
\text { kumbangpadi }\end{array}$ & large niltava \\
\hline & Muscicapidae & Ficedula hyperitra & Sikatan bodoh & $\begin{array}{l}\text { snowy-browed } \\
\text { flycatcher }\end{array}$ \\
\hline & Muscicapidae & Ficedula mugimaki & $\begin{array}{l}\text { Sikatan } \\
\text { mugimaki }\end{array}$ & $\begin{array}{l}\text { mugimaki } \\
\text { Flaycatcher }\end{array}$ \\
\hline & Muscicapidae & Ficedula wastermani & Sikatan belang & little pied flycatcher \\
\hline & Muscicapidae & Cinclidium diana & Berkecet biru tua & sunda robin \\
\hline & Sylviidae & Pyloscopus borealis & Cikrak kutub & arctic warbler \\
\hline & Sylviidae & Seicercus castaniceps & $\begin{array}{l}\text { Cikrak mahkota } \\
\text { kuning }\end{array}$ & $\begin{array}{l}\text { chestnut-crowned } \\
\text { warbler }\end{array}$ \\
\hline & Sylviidae & Pyloscopus trivigatus & Cikrak daun & $\begin{array}{l}\text { Mountain leaf } \\
\text { warbler }\end{array}$ \\
\hline & Sylviidae & Orthotomus cuculatus & Cinenen gunung & mountain tailorbird \\
\hline & Rhipuduridae & Rhipidura albicolis & Kipasan gunung & white-throated fantail \\
\hline & Nectarinidae & Arachnothera longirostra & Pijantung kecil & little spiderhunter \\
\hline
\end{tabular}

Untuk mengetahui burung strata bawah dilakukan dengan menggunakan metode metoda Mist net (jaring kabut). Metoda ini yaitu metoda yang digunakan untuk mendapatkan deskripsi jenis-jenis burung dengan melakukan penangkapan langsung, pengukuran morfometri dan pencincinan burung tersebut.14 jaring kabut dipasang secara seri pada lokasi pengamatan yang diperkirakan merupakan habitat bagi burung. Jaring kabut dipasang 
sedemikian rupa diantara vegetasi pada hutan G. kerinci dan G. tujuh selama lima hari masing-masing lokasi, yaitu dimulai pukul 06.00wib-18.00wib dengan interval pengecekan 1X 60 menit. Burung yang tertangkap akan dilakukan pencincinan dengan nomor cincin khusus dari IBBS (Institut Bird Banding Schem) dengan kerja sama dengan Pusat Ilmu Pengetahuan Indonesia (LIPI). Identifikasi jenis menggunakan buku daftar burung jenis Indonesia 2, Mackinnon, dkk 1993 dan MacKinnon dkk. 2010.

\section{HASIL DAN PEMBAHASAN}

Sebanyak 83 individu dari 21 spesies, enam famili dan semuanya berasal dari ordo Passeriformes berhasil ditandai selama penelitian ini. Jenis pada masing-masing famili dapat dilihat pada Tabel 1.

Spesies terbanyak yang tertangkap pada jaring kabut diperoleh dari famili Timaliidae dan Muscicapidae. Famili Timaliidae terdiri dari enam jenis dan Muscicapidae lima jenis. Sedangkan untuk jumlah individu tertinggi yaitu Stachyris nigricep sebanyak 26 individu dari famili Timaliidae kemudian diikuti oleh spesies Ficedula hyperitra sebanyak 12 individu dari famili Muscicapidae. Kesemua spesies yang tertangkap merupakan spesies yang menggunakan tempat hidup dan mencari makan di habitat ketinggian relung tiga meter karena dari semua jenis yang ditemukan merupakan jenis burung yang hidup di habitat semak . Pada lokasi pengamatan ini banyak terdapat pohon dan semak yang merupakan habitat yang baik bagi burung.

Struktur komunitas burung strata bawah di daerah tropis mewakili sistem yang sangat baik untuk melihat perbedaan sensifitas antar spesies terhadap variasi habiat dalam skala yang bereda (Willson dan Comet, 1996). Keanekaragaman jenis burung dipengaruhi oleh banyak faktor diantarannya kelimpahan epifit, kelimpahan buah-buahan, keterbukaan lantai hutan dan komposisi jenis pohon. Umumnya kawasan hutan pegunungan akan memiliki jumlah jenis angka relatif tinggi, bila dibandingkan dengan padang rumput yang produktifitasnya rendah. Hal ini disebabkan komposisi yang cendrung melimpah sehingga memliki jumlah jenis burung yang beragam .

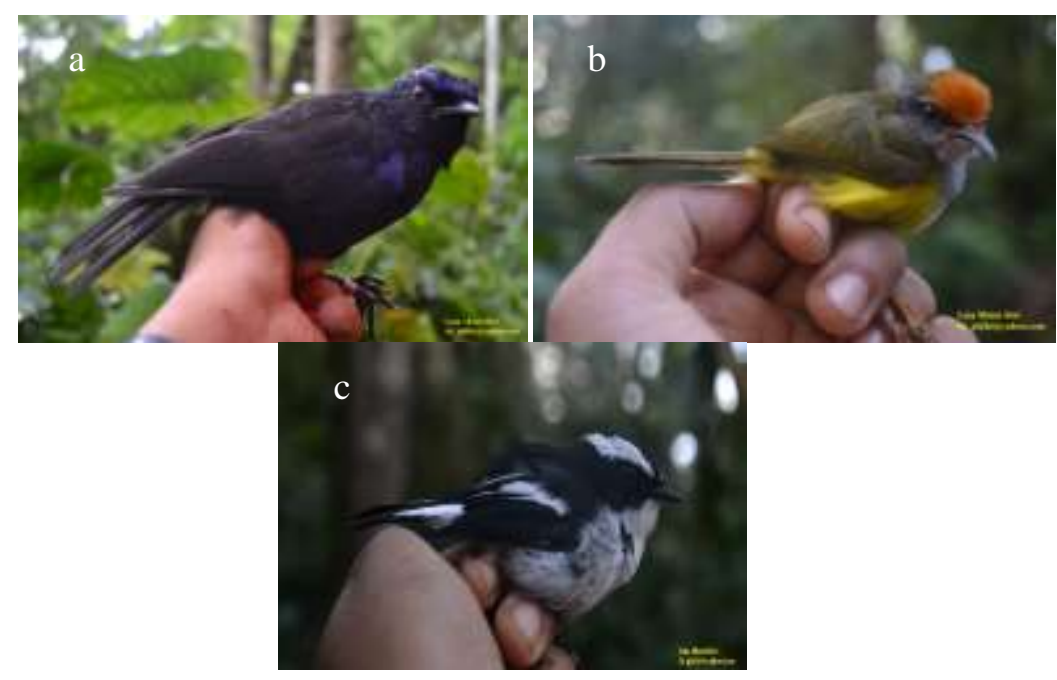

Gambar 1 Burung Hasil Identifikasi dari Berbagai Spesies a. Myopinius melanorus, b. Orthotomus cuculatus dan c. Ficedula wastermani 


\section{KESIMPULAN DAN SARAN}

\section{Kesimpulan}

Sebanyak 84 individu burung tertangkap dan ditandai dalam penelitian ini. Semua jenis yang tertangkap pada penelitian ini semua jenis burung yang hidup di strata bawah (understory) dengan habitat hutan dan jenis burung ini merupakan jenis burung yanh habitatnya semak.

\section{Saran}

Keanekaragaman jenis burung di suatu daerah perlu dilakukan khususnya untuk jenisjenis burung strata bawah karena sangat berpengaruh terhadap terhadap ketersediaan habitat untuk hidup burung-burung. Untuk itu perlu dilakukan penelitian ini dengan waktu lebih lama.

\section{DAFTAR KEPUSTAKAAN}

Bibby, C. Martin, M. Stuar, 2000. TeknikTeknik Ekspedisi Lapangan Survey Burung. Birdlife International Indonesia Programme. Bogor-Indonesia.

MacKinnon, J and Phillips, K. 1993. Field guide to the birds of Sumatera, Borneo, Java and Bali. The greater Sunda Islands. Oxford. Oxford University Press.

MacKinnon, J. 1991. Panduan Lapangan Pengenalan Burung Jawa dan Bali.
Gadjah Mada University Press.
Yogyakarta.

MacKinnon, J. K Phillip dan Van Balen. 2000. Burung-burung di Sumatera, Jawa, Bali dan Kalimantan. Puslitbang Biologi LIPI. Jakarta.

Novarino., H. Kobayasi, A. Salsabilah,Jarulis, M.N. Janra.2008. Panduan Lapangan Pencincinan Burung di Sumatera. Perpustakaan Nasional.

Novarino, W., A. Mardiastuti., Prasetyo L.B,W. Reviany, Mulyani Y.A, H. Kobayasi, A. Salsabilah, Jarulis , M.N. Janra. 2008. Guild Composition and Niche Breadth of Undestrory Bird in Sipisang West Sumatera.

Sujatnika, P. Jepson, T.R. Suhartono, M.J. Crosby, A. Mardiastuti. 1995. Conversing Indonesian Biodiversity. The Endemic Bird Area Approach. PHPA/Birdlife International -Indonesia Programme. Bogor.

Sukmatoro W., M. Irham, W. Novarino, F. Hasudungan, N. Kemp, M. Muchtar. 2007. Daftar Burung Indonesia no. 2. Indonesia Ornithologists' Union. Bogor

Willson M.F. and Comet, T.A. 1996. L. Bird communities of Northern forests: Ecological Correlates of diversity and aboundance in the understory. Condor 98:358-362 